\title{
Movement-Countermovement Dynamics in a Land Use Controversy
}

\author{
Alison E. Adams ${ }^{1}$ \\ School of Forest Resources and Conservation \\ University of Florida, Gainesville, United States \\ Thomas E. Shriver \\ North Carolina State University, Raleigh, United States \\ Chris M. Messer \\ Colorado State University-Pueblo, United States
}

\section{Abstract}

Recent studies have highlighted the ways in which activism can be suppressed in democratizing nations, yet much of this work tends to be state centered. Our research examines the role that private actors play in the repression of environmental activism in post-socialist Czech Republic. Following the 1989 collapse of the communist regime, the environmental movement experienced a brief period of widespread public support, which quickly gave way to anti-environmental trends and the general vilification of environmental activists. Drawing from indepth interview data, newspaper coverage, and direct observation, we analyze a contentious highway bypass controversy around the city of Plzeñ. Results indicate that environmentalists have been forced to contend not only with political hostility, but also with organized forms of public opposition from an anti-environmentalist countermovement organization.

Keywords: countermovements, democratization, environmentalism, land use, social movements

\section{Introduction}

In response to the deplorable environmental problems left in the wake of socialist rule, public environmental concern reached its peak shortly following the 1989 Velvet Revolution (Jehlička, 1999; Moldan \& Hak, 2000). During this critical transition period, the burgeoning Czech environmental movement experienced widespread support for its campaigns. However, environmental concern soon waned among the public as attention shifted to the country's economic stability and development as it transitioned from a socialist system. As economic

1 Corresponding author: alison.adams@ufl.edu. 
anxiety intensified throughout the country, environmental concern gave way to anti-environmental attitudes and the general vilification of environmental activists (Jehlička, 1999; Pavlínek \& Pickles, 2000; Shriver \& Messer, 2009; Slocock, 1996). Our analysis of an environmental controversy surrounding the placement of a highway bypass in the western Bohemian region of the Czech Republic highlights how the environmental movement strategically designed a campaign in this post-socialist context. Moreover, we examine how a private countermovement organization exploited anti-environmental public sentiments in order to successfully defeat the environmental activists.

Scholars have called for greater attention to the role of private actors as agents of protest control in studies of social movement repression (Earl, 2004, 2006; Ferree, 2005; Meyer \& Staggenborg, 1996). It is particularly important to examine how these private agents affect social movement tactics, and ultimately how the activities of private opponents impact social movement success. Studies that focus on private agents of social control have paid particular attention to the importance of countermovements in the context of protest control, noting how they make tactical choices, strategically frame their messages, and enact social and political change (Dixon, 2008; Fetner, 2001; Griffin et al., 1986; Isaac, 2002; Lo, 1982; Meyer \& Staggenborg, 1996; Mottl, 1980). We know that the dynamics between countermovements and their target social movements can shape activism and influence policy and the political process (Andrews, 2002; Dixon, 2008). Although much of this research is situated in mature democracies, what is lacking is an understanding of how these dynamics play out in other political contexts.

Building upon previous work on movement-countermovement dynamics as well as elite-driven countermovements, we examine the tactical interplay between an environmental movement and its opposition in the Czech Republic. We use the case of an environmental controversy surrounding the construction of a highway bypass in the industrial city of Plzen to examine: (1) how movement-countermovement interactions and tactical choices unfold within the post-socialist context; and (2) how the interplay between these two groups influenced public reactions toward this environmental controversy. The ethnographic data used for this project include in-depth interviews with environmentalists, government officials, and private citizens organized to oppose environmental activists. We also utilized direct observation of protest events and analyzed newspaper coverage of the environmental controversy. This unique data set allowed us to analyze the strategies and tactics used by both environmentalists and their opponents. Findings suggest that the tactical interplay between environmental movements and their opposition in postsocialist societies can precipitate success or failure depending on broader trends in public environmental attitudes. 


\section{Movement-countermovement dynamics and tactical repertoires}

While many social movement scholars have focused on the conflict-repression nexus between social movements and the state (Boykoff, 2007; Cunningham, 2003; Johnston \& Mueller, 2001; Koopmans, 2005), comparatively little research has highlighted the role of private actors as agents of social control (Earl, 2004, 2006; Ferree, 2005; Meyer \& Staggenborg, 1996). Numerous scholars have adopted Tilly's (1978, p. 100) conceptualization of repression: "any action by another group which raises the contender's cost of collective action" (e.g., Earl, 2004; Meyer \& Staggenborg, 1996). This broad definition encompasses more traditional forms of repression by the state as well as non-state agents. Earl (2004) explicitly urges social movement analysts to focus on private agents of repression. More specifically, social movement scholars have echoed the need for analyses of how private countermovements influence social movement protest (Earl, 2004, 2006; Linden \& Klandermans, 2006; Meyer \& Staggenborg, 1996).

Private countermovement organizations can play a significant role in controlling and disrupting social movement activity, yet relatively little attention has been paid to the function of these groups in social movement research (Dixon, 2008; Griffin et al., 1986; Isaac, 2002). Countermovements are conceptualized in several ways in social movement literature. At their core, countermovements are defined as organizations that specifically work to oppose established social movements (Fetner, 2001; McCarthy \& Zald, 1977; Meyer \& Staggenborg, 1998). In this sense, they are characterized as reactive movements (Mottl, 1980; Useem, 1980). While these movements may arise in response to existing social movements, most often they act in tandem with social movements to oppose their tactics and goals (Meyer \& Staggenborg, 1996). However, if the movement and countermovement coexist for long enough, they can be empirically uncoupled into two oppositional movements rather than a movement-countermovement pair (Andrews, 2002; Meyer \& Staggenborg, 1996).

Research on movement-countermovements relations often focuses on how and why countermovements emerge. Primarily, the target social movement must be perceived as potentially successful (Andrews, 2002; Meyer \& Staggenborg, 1996). If the target social movement is able to reach its goals, the countermovement arises to neutralize those efforts (Meyer \& Staggenborg, 1996). In addition, a social movement's use of "successful" tactics can serve as a model for emergent countermovements to design similar approaches to protest (Meyer \& Staggenborg, 1996; Zald \& Useem, 1987). In this way, the very preexistence of a social movement can create the social and political space for a countermovement to emerge. 
Scholars have parsed different types of countermovements, but they have paid particular attention to organizations that have elite ties. Compared to more traditional social movements, countermovements are often described as having connections to both local and non-local authorities, placing them in a more advantageous structural location (Gale, 1986; Griffin et al., 1986; Lo, 1982; Mottl, 1980; Pichardo, 1995). Pichardo (1995, p. 42) describes these connections as "institutional linkages." While most movements try to develop alliances with elite actors in some capacity (Meyer \& Staggenborg, 1996; Tarrow, 1994), elite-driven countermovements have elite founders and leaders who drive the movements' agenda and tactical choices (Austin, 2002; Earl, 2004; Pichardo, 1995). Elite-driven countermovements often arise when either the elites are the direct targets of social movement activity, or when elite interests are threatened by social movement activism.

Elite-driven countermovements often take on the appearance of citizen-based grassroots movements (Earl, 2004; Pichardo, 1995). These organizations often have access to additional resources and support, but they also have greater ability to mobilize the general public to oppose genuine grassroots movements and work toward elite ends. For example, several scholars have highlighted the role of elite-driven movements that take on the appearance of grassroots organizations in "manufacturing uncertainty" in the debate about global climate change (Dunlap, 2013; Oreskes \& Conway, 2010; Powell, 2011). This research has shown how elite-driven countermovements not only shape public opinion, but can rally opposition against environmental activist groups. These types of groups are also distinguished by their strategic approaches. Pichardo (1995) distinguishes elite-driven countermovements from other types of private countermovements with the presence of vigilantism. Importantly, elite-driven movements' influence with local authorities can afford them leeway in the context of violent tactics or vigilantism (Earl, 2004; Pichardo, 1995).

Although previous work has provided guidelines for defining elite-driven countermovements, identifying them in practice can be challenging. It can be problematic to distinguish an elite-driven countermovement from a countermovement that simply has elite alliances. In other words, how does one differentiate between elite support and elite leadership? We define elite-driven countermovements as those that are founded, controlled, and constituted by powerful institutional actors. In contrast, elite-allied countermovements enjoy support and resources from elites, but are founded, controlled, and constituted by non-elite actors. Irons (2006, p. 177) notes, "Current theories of movement repression understate the complexity and variability of the statecountermovement relationship. State and society can overlap in the effort of protest control in multiple ways. However, the assumption that such overlap automatically translates into a fully aligned effort is problematic." Thus, 
the nature of an organization's elite connections can be clandestine, and the composition of the membership base may be unclear. However, distinguishing between elite-driven and elite-allied countermovements has important theoretical and conceptual implications for understanding strategic approaches and tactical choices.

While burgeoning research on movement-countermovement relations has identified some key conceptual and empirical findings (Fetner, 2001; Lo, 1982; Meyer \& Staggenborg, 1996, 1998; Mottl, 1980; Zald \& Useem, 1987), additional work is needed to unpack the relationships and outcomes associated with these complex interactions. Movement-countermovement dynamics have been described as a conjoint process where both sides influence each other as well as the broader political and social milieu (Fetner, 2001; Gamson \& Meyer, 1996; Meyer \& Staggenborg, 1996; Miceli, 2005). In this process, it is important to highlight what we term tactical reflexivity, or the willingness and ability of movements to adapt their tactical approaches to changing internal and external circumstances. The ability to alter tactical approaches is especially important in the context of movement-countermovement contention (Meyer \& Staggenborg, 1996). Tactical choices range from extra-institutional tactics, such as violent public protest, to institutional approaches, such as lobbying. The scope of a movement's tactics shapes its contention with countermovements, and likewise the interplay between movements informs the development and adaptation of tactical repertoires (Dixon, 2008; Griffin et al., 1986; Rohlinger, 2006).

Much of the research regarding the tactical interplay between movements and countermovements indicates that the antecedent movement sets the tone for the oppositions' tactical choices. Furthermore, the countermovement must often "parallel" the tactics of the target movement in order to retain a tactical advantage. While there may be nuanced differences in the tactical repertoires of either side of the conflict, the countermovement often must engage in the same political or social sphere as its target movement (Dixon, 2008; Meyer \& Staggenborg, 1996). The ensuing process of protest and counter-protest involves responding to and opposing frames and claims from each side (Dixon, 2008; Mottl, 1980). For social movements, this work is ancillary to protest efforts aimed at the movement's original goals of social or political change, and thus can potentially redirect crucial organizational resources away from its original targets.

We argue that research on the tactical interplay between movements and countermovements must take three issues into account. First, the end goal of oppositional tactical maneuvering is achieving a favorable position for the movement. If a social movement organization is put on the "defensive," or put into a position where it must continually retaliate against oppositional framing, it can be at a significant tactical disadvantage. Second, movements must be willing 
to adapt their tactical repertoires (Hewitt \& McCammon, 2004) and to draw from a diverse arsenal of tactics that can work in multiple protest settings (Dixon, 2008). Tactical flexibility increases a movement's effectiveness in achieving its goals. Third, countermovement efforts can both thwart social movement success and impede a social movement's ability to protest (Meyer \& Staggenborg, 1996).

While extant research has provided considerable insights into the complex relationship between movements and countermovements, most of this work has focused on protest activity that occurs in mature democracies. We believe that such dynamics are heavily influenced by the political context as well as the substantive topic under debate. What is unclear in previous work is how dynamics between social movements and countermovements play out in a postsocialist context. In what ways do the tactical choices of each side of the conflict precipitate movement success or failure? Moreover, how can the interplay between an environmental movement and its countermovement affect public environmental attitudes, particularly in a newly developed democracy?

\section{Methods}

The data for this project come from ethnographic research and include indepth interviews, direct observation, and review of archival and secondary sources. As part of a larger research project on environmental activism in the Czech Republic, the second author conducted fieldwork over a 10-year period, between 2000 and 2009. Semi-structured interviews were conducted with 135 respondents. The full data set provides contextual backdrop of the Czech environmental movement. For this project, however, we focus on in-depth interviews with environmentalists associated with Children of the Earth (Déti Zemé) (CoE), government officials involved in the Plzeň bypass controversy, and members of the countermovement organization, Group for the Highway (občanské sdruženi Dálnice) (GfH). ${ }^{2}$

Initial contacts were established with representatives of $\mathrm{CoE}$ through visits to the regional office in Plzeň and the national headquarters in Prague. We interviewed key leaders from $\mathrm{CoE}$ and then used a snowball sampling technique to identify additional activists. Similarly, initial interviews were conducted with the leaders of the countermovement organization GfH. Through snowball sampling we conducted additional interviews with GfH supporters over the next two years. In-depth interviews were also conducted with governmental officials close to the Plzeň controversy who offered their critical assessments of CoE.

2 The countermovement organization was officially registered with the government in September 1997 as občanské sdružení Dálnice, or civic group Highway. For clarity in translation, however, we refer to the organization as Group for the Highway (GfH) throughout the analysis. 
Archival research and reviews of relevant newspaper coverage provided additional sources of data for this project. We reviewed hundreds of internal environmental movement documents housed at national and regional headquarters of CoE. These data provided invaluable materials not only for constructing the history of the controversy, but also for analyzing the strategies and tactics used by environmentalists and their opponents. We also reviewed nearly 300 newspaper articles on the Plzen highway bypass controversy between 1999 and 2001, the peak of the public controversy. Nearly two-thirds of these newspaper articles were published in the regional newspaper, Plzeňský deník. We also collected and reviewed relevant news articles from Mladá fronta, Právo, Lidové noviny, and Hospodářské noviny. Newspaper coverage of the bypass controversy provided significant context for the case and allowed us to better understand the tactical choices used by competing sides.

\section{The origins of the bypass controversy in Plzeň}

Our analysis begins by examining the details of the Plzen̆ bypass conflict. Our findings detail how the environmental organization CoE developed a repertoire of institutional tactics in order to promote a bypass option that would be less damaging to the local environment. We highlight how post-socialist environmental legislation and CoE's reliance on legal and institutional strategies influenced this environmental controversy.

\section{The history of the Plzeň bypass and relevant post- socialist environmental legislation}

The city of Plzeň, located in the western Bohemian region of the Czech Republic, has a history of significant issues associated with air pollution. As a hub for four main transport corridors, Plzeň most notably experienced extensive air pollution from heavy traffic congestion. Large trucks made up a significant portion of the traffic, contributing noxious emissions and noise pollution. Both residents and city officials attributed the worst of the air quality problems to the poorly planned highways of the socialist era. The high volume of exhaust from commercial traffic was often trapped by temperature inversion and, as a result, the air pollution was severe enough to choke local residents. In the 1990s, residents began to press officials to move forward with plans to construct a bypass that would redirect traffic away from the city center. A GfH member in the city's center illustrated the urgency of the situation:

The quality of the air in Plzen is horrible. All of this is because of the bypass. We don't have a highway bypass. There are so many cars and 
trucks driving through Plzeň everyday because we don't have a highway that will lead around Plzeň. So the emissions and smog in the center is unbearable. (interview with GfH representative, May 19, 2000)

Recent research has linked the pollution problems in Plzeň to health problems among its residents, specifically noting alarmingly high rates of kidney and colon cancer (Holt, 2010). Aware of these issues, many residents are concerned for their own health as well as the health of the area's children. But despite widespread agreement on the need for a bypass, the debate about where to place the bypass persisted for over a decade.

In 1990, officials considered bypass variants both to the north and south of Plzeň (Konopásek et al., 2008). In response, a coalition of residents in the south protested the proposals for the southern variants. In 1991, a large team of experts analyzed both north and south options and recommended the southern variant (known as the $\mathrm{K}$ variant). The recommendation was presented to local and national authorities and negotiations ensued. Although Plzeň's local health official felt that the northern variant was a better choice, the Plzeň municipality, then prime minister Petr Pithart, and the Czechoslovakian Minister of the Environment endorsed the recommended $\mathrm{K}$ variant in the south.

In response to the government support for the southern option, residents of the villages Brucna and Cernice (near the proposed K variant) organized a petition in 1991 and 1992 against this variant. An environmental activist described this coalition of residents, known as the Petition Committee, as a group of wealthy citizens with elite connections: "The residents of these areas are very influential, the wealthy upper class of the community. The chief of the Petition Committee is the head of the West Bohemia Energy Works. This is a person in a very influential position. And, they had very strong connections with the local government in Plzeň" (interview with CoE representative, June 8, 2000). The Petition Committee actively promoted an alternative southern route away from Brucna and Cernice, known as the $S$ variant. They called for a new expert analysis of the options in 1992, which resulted in a recommendation for the $S$ variant.

At the same time, significant environmental legislation was passed that facilitated the public's participation in the democratic process. The government passed new environmental laws designed to address the legacy of severe environmental damage left in the wake of the socialist regime. Essentially, these laws provided guidelines and regulations for the environmental assessment of additions to the legislation, planned activities (e.g., construction of new motorways), and public participation in environmental decision-making. The most salient portions of 
this new legislation were procedures for environmental impact assessment (EIA) that specifically allowed for public participation in environmental decisionmaking.

The trend of environment-focused legislation did not last long, however. After the bifurcation of Czechoslovakia into the Czech Republic and Slovak Republic in January 1993, Václav Klaus, a leader in the conservative Civic Democratic Party (Občanská demokratická strana), served as prime minister of the Czech Republic. $\mathrm{He}$ and his followers began a campaign targeted toward environmental activists and organizations, fostering a widespread anti-environmental sentiment among the Czech public. The new government passed Decree No. 631, The Development of Motorways and Expressways Up to 2005, which charted direction for the progression of highway planning. Significantly, the decree passed without any public discussion despite the EIA process, which required public participation in any new conceptual additions to environmental legislation.

In 1993, a team of experts conducted an EIA to assess potential environmental effects of the proposed bypass variants in Plzeň. Among other data, the assessment relied heavily on the 1992 analysis that recommended the S variant. The team drew considerable criticism for using a biased analysis to inform its recommendation, using faulty data collection procedures, and making a recommendation without sufficient information. Nevertheless, the EIA team recommended the S variant, as proposed by the Petition Committee. This longer variant would be situated further from the wealthier areas of Plzeň and would cut through Valík Hill (an environmentally protected area), near the Plzeň villages of Radobyčice, Štěnovice and Útušice (Konopásek et al., 2008).

Based on the EIA's recommendation for the S variant, the Ministry of the Environment approved a version of this variant in 1994, known as the SUK2. The Water Resource Office challenged the decision, claiming that the SUK2 would pose a significant threat to Plzeň's only source of drinking water, and significant opposition to the SUK2 arose among Plzeň residents. The residents of Štěnovice and Útušice organized a group called the Association for the Protection of Valík Hill. This citizen-based organization needed help in dealing with the complex legal and scientific issues associated with the bypass controversy. They reached out to $\mathrm{CoE}$, an environmental organization with more experience in these types of battles.

\section{Children of the Earth and the campaign for the K variant}

CoE formed in September 1989, just three months before the Velvet Revolution. Following the revolution, the activists involved with CoE seized the new opportunities associated with the burgeoning democracy and established 
CoE as an official non-governmental organization (NGO) in Prague in 1990. The group focused mainly on the environmental aspects of transport issues, waste, and environmental protection. The organization received funding from international NGOs as well as the European Union. The Plzen̆ branch of CoE was established in 1990, and in 1994 the Association for the Protection of Valík Hill requested CoE's help with the bypass issue. The Plzeň branch included about 20 core members, but many other environmental activists, NGOs, and concerned citizens became involved.

Like the broader environmental movement, $\mathrm{CoE}$ was galvanized by the freedoms and rights available through the post-socialist state. As a result, the group shifted from a tactical repertoire of direct actions to a new set of institutional tactics to lead in the fight for the $\mathrm{K}$ variant. Importantly, the environmentalists decided to work within legal and governmental arenas. A veteran environmentalist who had been active in $\mathrm{CoE}$ at the national level described how their shift to institutional tactics coincided with the introduction of environmental legislation in the early 90s:

Of course in the beginning of the 1990s, we were doing more direct actions. We didn't have experience [with legal tactics] and there were no opportunities to participate in the hearings, so mostly we were doing petitions, public events, and writing letters to parliament members. This was until 1994 or 1995. Then we started participating in EIAs ... It was then that we started taking advantage of legal strategies. (interview with CoE representative, July 8, 2002)

CoE attempted to take advantage of environmental legislation adopted in the post-socialist period, which opened the door to participation in the decisionmaking process. An environmentalist with $\mathrm{CoE}$ explained their approach to the highway controversy:

There are several mechanisms to involve the public in decision-making ... The law regarding the protection of the environment and the landscape is the most important because it allows civic organizations to participate in all phases of decision-making. Citizens' organizations have the right to appeal and have access to relevant documents. (interview with CoE representative, June 8, 2000)

The environmental group's initial tactics established their participation in the bypass decision-making process; they filed two constitutional complaints in 1994. The first complaint was against the 1993 passage of Klaus's Decree No. 631. The group argued that the decree should not have been passed without being subject to public debate, as per the new EIA. The court upheld the decree because it was seen as an improvement to existing legislature rather than a new 
concept, and thus was not subject to public discussion. CoE partnered with the residents of Štěnovice and Útušice to file a second constitutional complaint regarding the revocation of the recommendation for the $\mathrm{K}$ variant; however, since the complaint was lodged after the allotted time for challenges to be filed, the courts refused to hear it.

$\mathrm{CoE}$ and local residents' strategic efforts were successful in raising concern about environmental issues associated with the bypass. In 1995, an office within the Ministry of the Environment conducted an environmental assessment of the SUK2 on Valík Hill. The office ultimately recommended the K variant as the best environmental option. Nonetheless, the Minister of the Environment conceded to pressures from the other officials and recommended the SUK2 variant on March 15, 1995. Consequently, the local Planning and Control Office in Plzen issued a territorial decision paving the way for the construction of the SUK2 in December 1995.

The disconnect between the 1995 assessment that recommended the K variant and the ensuing endorsement of the SUK2 heralded problems for the environmental activists. Some CoE activists felt that their faith in the democratic system and their reliance on an institutional tactical repertoire may have been misguided. Importantly, authorities restricted citizens' ability to participate in this decision by limiting the time to file a complaint from 15 to 10 days. CoE immediately asked why the Minister of the Environment had rejected the recommendation for the $\mathrm{K}$ variant and threatened to take the issue to court. The environmental activists felt that the minister's recommendation and the ensuing territorial decision from the local Planning and Control Office signaled that the democratic process was failing.

In an attempt to solidify their position as legitimate participants in the bypass decision-making process as well as potentially delay construction of the SUK2, $\mathrm{CoE}$ activists decided to communally purchase a strip of land across the proposed route. CoE felt that this intensification of their institutional tactics would allow them to voice their concerns as landowners rather than as an NGO. At the time of the land purchase, Czech legislation was unclear as to how and to what extent NGOs could participate in official decision-making, but landowners were seen as vital participants. However, the strategy backfired as it left $\mathrm{CoE}$ vulnerable to oppositional rumors and they severely underestimated how the public would perceive their efforts. Plzeň citizens rejected the land trust strategy, accusing CoE of employing extremist tactics. An environmentalist who took part in the land trust described public perceptions of this tactic:

[The land trust] has been very bad for our image ... In 1995, it looked like a very good idea, but now the people of Plzen are very angry with us. Journalists write that we are trying to block the bypass by purchasing 
the strip of land ... These are just rumors, but you have no chance to tell people, "No, it's not true." (interview with CoE representative, June $8,2000)$

In 1996, CoE persevered with their legal campaign for the $\mathrm{K}$ variant. The Minister of Regional Development issued a territorial decision, decreeing the bypass would cut through Valík Hill in the form of a transit tunnel, based on the endorsement of the SUK2 in 1995. CoE immediately protested this decision and acted on their earlier threat to take legal action by jointly filing a lawsuit with several municipalities. In 1997, the Czech High Court ruled in favor of the environmentalists, finding the December 1995 territorial decision for the SUK2 variant illegal for two reasons. First, the director of the local Planning and Control Office limited the time allotted for citizens to object to the decision by five days. Second, whereas the 1993 EIA recommended the original S variant, the Planning and Control Office ultimately supported a modified version of this variant. As a result, the High Court authorized a new EIA, which would assess all possible variant options. At the time of the High Court decision, public support was in favor of the pro-K advocates; a local poll indicated that 46 percent of Plzeň citizens supported CoE.

\section{Stoking anti-environmentalism: Movement- countermovement dynamics in the bypass controversy}

In the mid-1990s, CoE appeared to be spearheading a successful campaign against the SUK2 variant, garnering support from many Plzeň residents. In response to the success of the campaign, however, an elite-driven countermovement organization emerged to oppose the environmentalists' efforts. We document how this countermovement fundamentally altered the highway controversy in Plzeň. Our analysis examines the tactical interplay between the environmental movement and countermovement, and highlights how broader trends in the post-socialist political landscape shaped these dynamics.

\section{The rise of the countermovement organization, Group for the Highway}

In September 1997, a countermovement organization, GfH, was established to oppose the efforts of $\mathrm{CoE}$ and their allies. GfH specifically worked to garner public support for the SUK2, and to erode public and governmental support for CoE. Unlike $\mathrm{CoE}$, GfH devised a tactical repertoire that strategically avoided legal and governmental avenues. Instead, they focused on fighting the environmentalists in the public sphere. In public statements, the countermovement claimed that 
environmentalists were purposefully delaying the construction of the bypass, and therefore endangering the health and well-being of Plzeň residents. During the height of their activities in 2000, an activist in GfH illustrated this sentiment:

I witnessed some old grandmother signing [one of CoE's] petitions and she didn't even know what she was signing ... It is just a bunch of nonsense that the environmentalists are doing. (interview with GfH representative, June 22, 2000)

GfH had institutional ties to Plzeň city authorities. Indeed, the countermovement's leader was a former member of the Plzeň City Council. After GfH was established in 1997, environmentalists noted a significant increase in opposition to their efforts from the city government. In 1998, a new mayor of Plzeň was elected, and he promptly prioritized the construction of the bypass. In numerous public statements and interviews, the mayor blamed CoE for the delays in the bypass construction. The new city authorities publicly accused CoE activists of being ecoterrorists. An environmental activist recalled his reaction to these statements:

In the Plzen case, the local government and the media took advantage of the situation, and they started blaming the environmentalists for the highway delay. I don't know of any "ecoterrorists" in the Czech Republic. I would like to see one, but there are none ... These people, these "ecoterrorists," would not be in environmental groups like Children of the Earth. (interview with CoE representative, June 8, 2000)

To further stoke the anti-environmentalist sentiment in Plzeň, city officials circulated a public opinion poll that was clearly slanted toward the SUK2. Officials used the results to publicize that support for the K variant in 1997 had shifted to the SUK2 because it would be finished faster. A member of CoE offered an explanation:

Plzen̆ citizens are very frustrated and that is understandable. It was necessary to find a target to place the blame on. The Plzeñ local government continues very intensely to put the blame of the highway bypass controversy on the environmentalists. (interview with $\mathrm{CoE}$ representative, June 24, 2000)

GfH began a targeted and strategic public relations campaign to disseminate antienvironmentalist messages. A GfH leader described how they used the media to defeat CoE: "They (CoE) are not able to prove their argument. The key issue is to disprove their arguments in the eyes of the media. So I'm disproving their arguments step by step" (interview with GfH representative, July 12, 2000). Environmentalists argued the countermovement's media campaign illustrated their willingness and desire to mislead the public. An environmentalist from $\mathrm{CoE}$ described their frustration with the countermovement's tactics: 
“[Countermovement leader's name] reports information about environmentalists to the newspapers, even when he knows it is not true. He just makes unfounded comments to the newspapers, and citizens are willing to believe them" (interview with CoE representative, June 24, 2000).

GfH frequently accused environmentalists of exploiting the democratic process to further their own agenda. A member of the countermovement explained:

When a group of 20 environmentalists put together a petition and get it signed by a thousand of their supporters, our democratic system calls this "public interest." From a legal point of view, this petition is considered worthy of government attention - it has legal power. The state can no longer stop these groups from doing this. Environmentalists are very aware of this fact. (interview with GfH representative, June 22, 2000)

A leader of $\mathrm{GfH}$ added that $\mathrm{CoE}$ exploited the legal system simply to delay construction of the bypass: "Environmentalists don't do anything except cause delays for the highway ... Every time they appeal, the court has to go through the entire case again. The environmentalists rely on the time it takes for the courts to make a decision just to delay the work that needs to be done" (interview with GfH representative, July 13, 2000). The respondent went on to say that the activists' efforts were wasted: "Ninety percent of these people [environmentalists] are all talk. They are not doing anything for the environment. Standing with a sign or a poster isn't going to do anything for the environment. The people who are really helping the environment are the ones doing research and publishing, not someone who is just arguing with the authorities" (interview with GfH representative, July 13, 2000). Another GfH member simply stated: "In Czech, environmentalists have replaced true ecology with their brand of pseudo protection of the environment" (interview with GfH representative, June 27,2000 ).

Environmentalists often explained that local newspapers were biased toward the city government and the elite-supported countermovement organization. CoE leaders pointed to the Plzen̆ Daily (Plzeňský denik) as particularly problematic. A member of CoE explained the nature of reporting on the bypass controversy: “I don't know why, but for some reason they [Plzen̆ Daily journalists] are on the side of Plzeň town hall officials on all of these environmental issues. You can see that the Plzen̆ Daily is not objective at all" (interview with CoE representative, June 4, 2001). Another environmental activist reported similar experiences with coverage of the conflict: "There was always something about me or Children of the Earth written in the Plzeň Daily, at least once or twice a week. And it was written in a negative way" (interview with CoE representative, June 5, 
2001). A member of CoE explained the success of the countermovement's media campaign against environmentalists, and why it was difficult for pro-K activists to fight back:

They [GfH and the Plzeň city government] started circulating lies that were easier to believe. We tried to answer with the truth, but this was not so easy to understand. Their lies were simple, but the truth was complicated. People received the simple lies much better than the complicated truths ... The truth is that the local newspapers were on the side of the town hall. So the local newspapers were publishing these simple lies, and our more complex arguments against it were almost never published. (interview with CoE representative, June 4, 2001)

\section{The escalation of countermovement tactics}

Following the second EIA for the bypass in 1998, the tactical interplay between $\mathrm{CoE}$ and GfH intensified. The EIA process followed the guidelines laid out by the Czech court. Community meetings allowed public involvement in the EIA process, documents were made widely available to NGOs, and the expert team that evaluated all possible variants used appropriate methods of data collection and analysis. In an effort to counteract claims made by GfH and the Plzeň city government, CoE went to the media and promised that they would support the EIA team's recommendation. The EIA team recommended a variant called the KUO, which was an amalgamation of the K and the SUK2 variants. The KUO was a longer option than the $\mathrm{K}$ variant, but would avoid cutting through Valík Hill and would be located closer to Plzeň.

After the recommendation for the KUO was made public, the Ministry of the Environment abrogated the former territorial decision regarding Valík Hill. Importantly, the annulment of this decision technically made the construction of the SUK2 illegal. Despite the recommendation of the new EIA, however, the Ministry of Regional Development failed to endorse the KUO, and instead continued with plans for construction of the SUK2. Following suit, the Plzen city government also rejected the KUO variant. Consequently, Plzeň officials issued a territorial decision for the SUK2 and authorized permits for the construction of several houses across the proposed KUO corridor.

$\mathrm{CoE}$ again relied on their repertoire of institutional tactics and threatened to take the violation of protocol to the courts, accusing the various ministries of backroom dealing and conflicts of interest. After the announcement that the Ministry of Regional Development would not support the KUO, CoE began receiving threatening phone calls. Activists suspected that the callers were either directly affiliated with GfH, or at the very least influenced by the 
countermovement's negative campaign against CoE. A leader of CoE played tapes of the phone messages for the second author in June 2000. He described the situation:

We contacted the police and told them that we were threatened ... There were some people that called us and said that we are bastards ... But there were also four threats that were really extreme where they said they will, in very bad words, they will hang us by our balls from the street lamps. (interview with CoE representative, June 24, 2000)

Despite the threats of violence, CoE moved forward with their efforts to challenge the territorial decision in the courts. Along with several other environmental NGOs, the activists wrote a letter to the Minster of Regional Development and requested an explanation for his failure to follow the recommendation of the second EIA. Ultimately, the ministry's rejection of the recommendation left many disenchanted with the process of public involvement in environmental decision-making.

Throughout 2000, both the Plzeň city government and GfH intensified their opposition to CoE. The mayor and his staff continued to make inflammatory statements to the press regarding environmentalists' role in the bypass conflict. Members of CoE noted the disparity in influence and power between the environmentalists and the countermovement group. Environmentalists alleged that GfH was founded by Plzeň elites. GfH's institutional linkages became apparent on May 18, 2000, when the countermovement organized a public demonstration with the support of city authorities and police. The demonstration was held on one of the main streets in Plzen̆ and was attended by several hundred supporters of GfH. Approximately 20 members of CoE also attended the rally, along with the second author. Several of the environmental activists held signs promoting the $\mathrm{K}$ variant. However, the demonstration quickly devolved, leading to threats and violence. A member of $\mathrm{CoE}$ who attended the rally described the interaction between GfH and $\mathrm{CoE}$ at the demonstration: "[The leader of GfH] attacked us. They also ruined our posters and billboards. They were cussing us in public" (interview with CoE representative, July 8, 2002).

The demonstration was flanked by a significant police presence. Many of the environmentalists expected the police to step in and reprimand GfH supporters. When the police intervened, however, it was the environmentalists who were forced out of the demonstration and across the street. CoE members reported hearing both police and countermovement supporters shouting that the environmentalists had no right to attend the public gathering. Several respondents attributed this to the countermovement's ties to the police and Plzeň city officials. 
Activists from CoE specifically chose non-violent tactics at the rally. While the group never used physical violence or threats to accomplish their goals, they realized that even the appearance of these types of tactics would be harmful to their image. The then leader of CoE explained their rationale:

We had a meeting before the demonstration. Normally, I carry pepper spray. I left it here because, really, the worst thing that could happen to us would be if the police say, "There were people from Children of the Earth and they had some kind of arms." We really could not do this. Also, we discussed whether we would use poles for signs or not. Because, people can say that the poles were not for signs, but for beating someone. So we were very careful. (interview with CoE representative, June 27, 2002)

Despite the unjust treatment of environmentalists, members from GfH circulated a petition for the SUK2 and gathered hundreds of resident signatures. The countermovement organization described the event as a success, and as further evidence that most Plzeň residents did not support CoE.

\section{The defeat of Children of the Earth}

In 2000, members of CoE and the pro-K coalition felt that they had to regain public support if they were going to be successful in the courts. The environmentalists filed a new lawsuit against the 1999 territorial decision for the SUK2 on the basis that it both rejected the recommendation made by the EIA and it ignored the Minister of the Environment's retraction of his support for the SUK2. In a final effort to turn public opinion back to their favor, CoE members posted flyers in buses and bus stations. The flyers explained that $\mathrm{CoE}$ was not trying to delay the bypass process with the lawsuit, and that the environmentalists were not against the bypass altogether.

Despite the opposition against them, the environmentalists were initially optimistic about the lawsuit. During interviews conducted in the summer of 2000, several members of CoE explained that they were expecting the High Court to rule in their favor. Moreover, the activists felt that a positive outcome in the courts would prompt Plzeň residents to turn their support back to CoE. For example, one activist explained:

We are right! We have the support of the experts! We are not like the people from Group for the Highway ... And on the other side, the side of Group for the Highway, there are only people from politics ... They have political power. But they have no experts! (interview with $\mathrm{CoE}$ representative, June 24,2000 ) 
At the time, CoE promised that they would withdraw from the bypass controversy if they lost the 2000 lawsuit in the High Court.

On 29 March 2001, the High Court handed down a ruling in favor of the SUK2, upholding the 1999 territorial decision. A few months later, parliament enacted a law specifically stating that the construction of the Plzen̆ bypass was a matter of public interest. The law allowed the Plzen city government and the project developer to circumvent many of the official procedures associated with motorway construction. Shortly after the announcement of the court decision, the national office of CoE announced they were officially abandoning the campaign. This decision was perceived as a betrayal by some members of CoE as well as the rest of the pro-K coalition who wanted to continue the campaign.

\section{Discussion and conclusions}

While previous research has primarily focused on movement-countermovement dynamics in mature democracies (Fetner, 2001; Lo, 1982; Meyer \& Staggenborg, 1996, 1998; Mottl, 1980; Zald \& Useem, 1987), our analysis of a highway bypass controversy highlights how these interactions played out in a post-socialist democracy. In response to severe air pollution in the city of Plzeň, both citizens and local authorities agreed there was an immediate need for a highway bypass to redirect commercial and residential traffic away from the city center. However, the placement of the bypass became a highly debated issue for more than a decade. The environmental group CoE relied primarily on institutional tactics to promote their preferred variant of the bypass. In response, the elite-driven countermovement GfH strategically promoted anti-environmentalist sentiment among the public.

Scholars have noted the importance of unpacking the complexities and nuances of elite ties to countermovements (e.g., Irons 2006), which is particularly important in cases of environmental disputes. We argue that these relationships may play out in different ways in terms of tactical repertoires. By examining the membership and connections of GfH, we were able to identify and analyze the group as an elite-driven countermovement. Our findings suggest that the countermovements' elite leadership and connections afforded the group substantial latitude in their use of retaliatory tactics against $\mathrm{CoE}$ (see also Earl 2004; Pichardo 1995). However, countermovements that are elite allied and do not have elite leadership may have less leeway for deploying extreme or unlawful tactical approaches. Thus, our research illuminates important questions for future research on elite-driven and elite-allied countermovements.

This research also highlights the importance of examining political context in analyses of movement-countermovement dynamics, especially in cases of 
environmental disputes. Our analysis revealed that the newly democratizing political system shaped the interplay between $\mathrm{CoE}$ and GfH in several important ways. First, at the time that the highway bypass options were debated in 1992, environmental legislation was passed that facilitated the public's participation in the democratic process. However, public participation in decision-making was new for both policymakers and for Czech citizens. Findings showed that CoE attempted to take advantage of this opportunity, but the rules for participation proved difficult to navigate. For example, the environmental group's land trust strategy was intended to legitimize their participation in the bypass debate; however, it caused both public and official opinion to turn against the group. Thus, whereas established democracies offer well-worn institutional avenues for social movements to participate in environmental discussions, activists must forge new strategic pathways in transitional and post-socialist countries.

In many cases of movement-countermovement interplay set in mature democracies, it is the social movement that develops a repertoire of extrainstitutional tactics and the countermovement that utilizes institutional avenues to oppose their target. However, our results highlight how movementcountermovement dynamics developed quite differently in a less mature democracy. Because the Plzeň bypass controversy took place in the decade following the 1989 revolution, the opposing sides of the conflict straddled the socialist and post-socialist eras. Consistent with trends in the broader environmental movement, CoE drew from the tactics afforded them by the new democratic system by adopting an institutional tactical repertoire. The activists became heavily involved in environmental decision-making as well as the legal system throughout their campaign for the $\mathrm{K}$ variant. In the months leading up to the 2001 High Court decision against CoE, the environmentalists were confident that proper legal procedure and objective expert opinion would ensure their victory over their opposition.

This case highlights the importance of tactical reflexivity for movement success, specifically in the context of environmental controversies. Previous work on countermovements highlights how countermovements often develop tactics that parallel those of their target movement (Dixon, 2008; Meyer \& Staggenborg, 1996); however, we argue that countermovements can identify their opponents' tactical blind spots and use them to their advantage. While CoE developed an institutional strategy, the elite-driven countermovement $\mathrm{GfH}$ drew from an entirely different arsenal of tactics. In addition to relying on their elite ties, the countermovement forced the conflict out of the courtroom and into the public sphere. In doing so, they gained widespread approval through an intensive media campaign designed to vilify environmentalists. The countermovement was able to take advantage of the existing bias in the media against environmental protest. In contrast, CoE failed to garner the support of Plzeň residents because 
they focused so intently on a purely institutional approach to activism. GfH capitalized on CoE's tactical mistakes and ultimately shifted both public and state support to their preferred version of the bypass.

Our findings reveal how movement-countermovement dynamics influence public opinion in the context of post-socialist environmental controversies. While environmental problems were in the spotlight of public attention at the time of the 1989 Velvet Revolution, environmental concern quickly diminished. From their inception in 1997, GfH tapped into broader trends of antienvironmentalism to engender doubt and distrust of environmentalists among the public. Their deliberate campaign against the environmentalists' agenda, coupled with CoE's failure to engage public support, resulted in a significant upswing in anti-environmental sentiment among the public.

\section{References}

Andrews, K. T. (2002). Movement-countermovement dynamics and the emergence of new institutions: The case of "white flight" schools in Mississippi. Social Forces, 80, 911-936.

Austin, A. (2002). Advancing accumulation and managing its discontents: The U.S. anti-environmental countermovement. Sociological Spectrum, 2, 71-105.

Boykoff, J. (2007). Limiting dissent: The mechanisms of state repression in the USA. Social Movement Studies, 6, 281-310.

Cunningham, D. (2003). The patterning of repression: FBI counterintelligence and the New Left. Social Forces, 82, 209-240.

Dixon, M. (2008). Movements, countermovements and policy adoption: The case of right-to-work activism. Social Forces, 87, 473-500.

Dunlap, R. E. (2013). Climate change skepticism and denial: An introduction. American Behavioral Scientist, 57, 691-698.

Earl, J. (2004). Controlling protest: New directions for research on the social control of protest. Research in Social Movements, Conflicts and Change, 25, 55-83.

Earl, J. (2006). Introduction: Repression and the social control of protest. Mobilization, 11, 129-143. 
Ferree, M. M. (2005). Soft repression: Ridicule, stigma, and silencing in genderbased movements. In C. Davenport, H. Johnston \& C. Mueller (Eds.), Repression and mobilization (pp. 138-155). Minneapolis: University of Minnesota Press.

Fetner, T. (2001). Working Anita Bryant: The impact of Christian antigay activism on lesbian and gay movement claims. Social Problems, 48, 411-428.

Gale, R. P. (1986). Social movements and the state: The environmental movement, countermovement, and government agencies. Sociological Perspectives, 29, $202-240$.

Gamson, W. A., \& Meyer, D. S. (1996). Framing political opportunity. In D. McAdam, J. McCarthy \& M. Zald (Eds.), Comparative perspectives on social movements: Political opportunities, mobilizing structures, and cultural framings (pp. 275-290). Cambridge: Cambridge University Press.

Griffin, L. J., Wallace, M. E., \& Rubin, B. A. (1986). Capitalist resistance to the organization of labor before the New Deal: Why? How? Success? American Sociological Review, 51, 147-167.

Hewitt, L., \& McCammon, H. J. (2004). Explaining suffrage mobilization: Balance, neutralization and range in collective action frames, 1892-1919. Mobilization, 9, 149-166.

Holt, E. (2010). Institute to investigate cancer hotspot in Czech Republic. The Lancet, 375,714 .

Irons, J. (2006). Who rules the social control of protest? Variability in the statecountermovement relationship. Mobilization, 11, 165-180.

Isaac, L. W. (2002). To counter the "very devil" and more: The making of independent capitalist militia in gilded age America. American Journal of Sociology, 108, 353-405.

Jehlička, P. (1999). The development of Czech environmental policy 1990-1995. Czech Sociological Review, 7, 37-50.

Johnston, H., \& Mueller, C. (2001). Unobtrusive practices of contention in Leninist regimes. Sociological Perspectives, 44, 351-375.

Konopásek, Z., Stöckelová, T., \& Zamykalová, L. (2008). Making pure science and pure politics: On the expertise of bypass and the bypass of expertise. Science, Technology, and Human Values, 33, 529-553.

Koopmans, R. (2005). The missing link between structure and agency: Outline of an evolutionary approach to social movements. Mobilization, 10, 19-33. 
Linden, A., \& Klandermans, B. (2006). Stigmatization and repression of extremeright activism in the Netherlands. Mobilization, 11, 213-228.

Lo, C. Y. H. (1982). Countermovements and conservative movements in the contemporary U.S. Annual Review of Sociology, 8, 107-134.

McCarthy, J. D., \& Zald, M. N. (1977). Resource mobilization and social movements: A partial theory. American Journal of Sociology, 82, 1212-1241.

Meyer, D. S., \& Staggenborg, S. (1996). Movements, countermovements, and the structure of political opportunity. American Journal of Sociology, 101, $1628-1660$.

Meyer, D. S., \& Staggenborg, S. (1998). Countermovement dynamics in federal systems: A comparison of abortion politics in Canada and the United States. Research in Political Sociology, 8, 209-240.

Miceli, M. S. (2005). Morality politics vs. identity politics: Framing processes and competition among Christian right and gay social movement organizations. Sociological Forum, 20, 589-612.

Moldan, B., \& Hak, T. (Eds.). (2000). Czech Republic 2000 ten years on: Environment and quality of life after ten years of transition. Prague: Charles University.

Mottl, T. L. (1980). The analysis of countermovements. Social Problems, 27, 620-635.

Oreskes, N., \& Conway, E. M. (2010). Merchants of doubt: How a handful of scientists obscured the truth on issues from tobacco smoke to global warming. New York: Bloomsbury.

Pavlínek, P., \& Pickles, J. (2000). Environmental transitions: Transformation and ecological defense in central and eastern Europe. New York: Routledge.

Pichardo, N. (1995). The power elite and elite-driven countermovements: The Associated Farmers of California during the 1930s. Sociological Forum, 10, 21-49.

Powell, J. L. (2011). The inquisition of climate science. New York: Columbia University Press.

Rohlinger, D. (2006). Friends and foes: Media, politics, and tactics in the abortion war. Social Problems, 53, 537-561.

Shriver, T. E., \& Messer, C. M. (2009). Ideological cleavages and schism in the Czech environmental movement. Human Ecology Review, 16, 161-171. 
Slocock, B. (1996). The paradoxes of environmental policy in eastern Europe: The dynamics of policy-making in the Czech Republic. Environmental Politics, 5, 501-521.

Tarrow, S. (1994). Power in movement: Social movements and contentious politics. New York: Cambridge University Press.

Tilly, C. (1978). From mobilization to revolution. Reading: Addison-Wesley.

Useem, B. (1980). Solidarity model, breakdown model, and the Boston antibusing movement. American Sociological Review, 45, 357-369.

Zald, M. N., \& Useem, B. (1987). Movement and countermovement interaction: Mobilization, tactics, and state involvement. In M. N. Zald \& J. D. McCarthy (Eds.), Social movements in an organizational society (pp. 247-272). New Brunswick, NJ: Transaction Publishers. 
This text taken from Human Ecology Review Volume 21, Number 1, 2015, published 2015 by ANU Press, The Australian National University, Canberra, Australia. 